W. R. F. GOUNDRY*, K. DAI, M. GONZALEZ, D. LEGG, A. O'KEARNEY-MCMULLAN, J. MORRISON, A. STARK, P. SIEDLECKI, P. TOMLIN, J. YANG (ASTRAZENECA, MACCLESFIELD, UK; CHANGZHOU SYNTHEALL PHARMACEUTICAL CO., LTD., CHANGZHOU AND ASYMCHEM LABORATORIES CO. LTD., TIANJIN, P. R. OF CHINA)

Development and Scale-up of a Route to ATR Inhibitor AZD6738

Org. Process Res. Dev. 2019, 23, 1333-1342.

\section{Synthesis of AZD6738}<smiles>O=C(O[Na])c1cc(Cl)nc(Cl)n1</smiles>
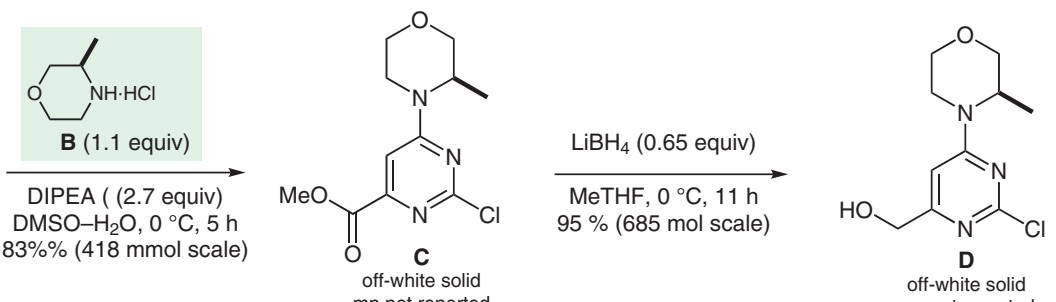

$96.7 \%$ pure (HPLC)

$95 \%$ (685 mol scale)

(1)

$\mathrm{MsCl}$ (1.2 equiv)

$\mathrm{Et}_{3} \mathrm{~N}$ (1.35 equiv)

$641 \mathrm{~mol}$ scale<smiles>CC1COCCN1c1cc(CS(C)=O)nc(Cl)n1</smiles>

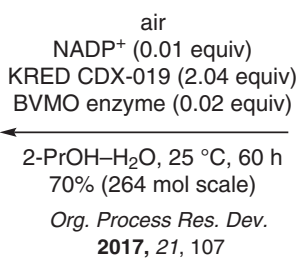

air
$\operatorname{NADP}^{+}(0.01$ equiv $)$

KRED CDX-019 (2.04 equiv) BVMO enzyme ( 0.02 equiv)

2- $\mathrm{PrOH}-\mathrm{H}_{2} \mathrm{O}, 25^{\circ} \mathrm{C}, 60 \mathrm{~h}$

$70 \%(264 \mathrm{~mol}$ scale)

Org. Process Res. Dev. 2017, 21, 107<smiles>CSCc1cc(N2CCOCC2C)nc(Cl)n1</smiles><smiles>COCc1cc(N2CCOCC2C)nc(Cl)n1</smiles>

off-white solid

) $=99.7: 0.3 \%$
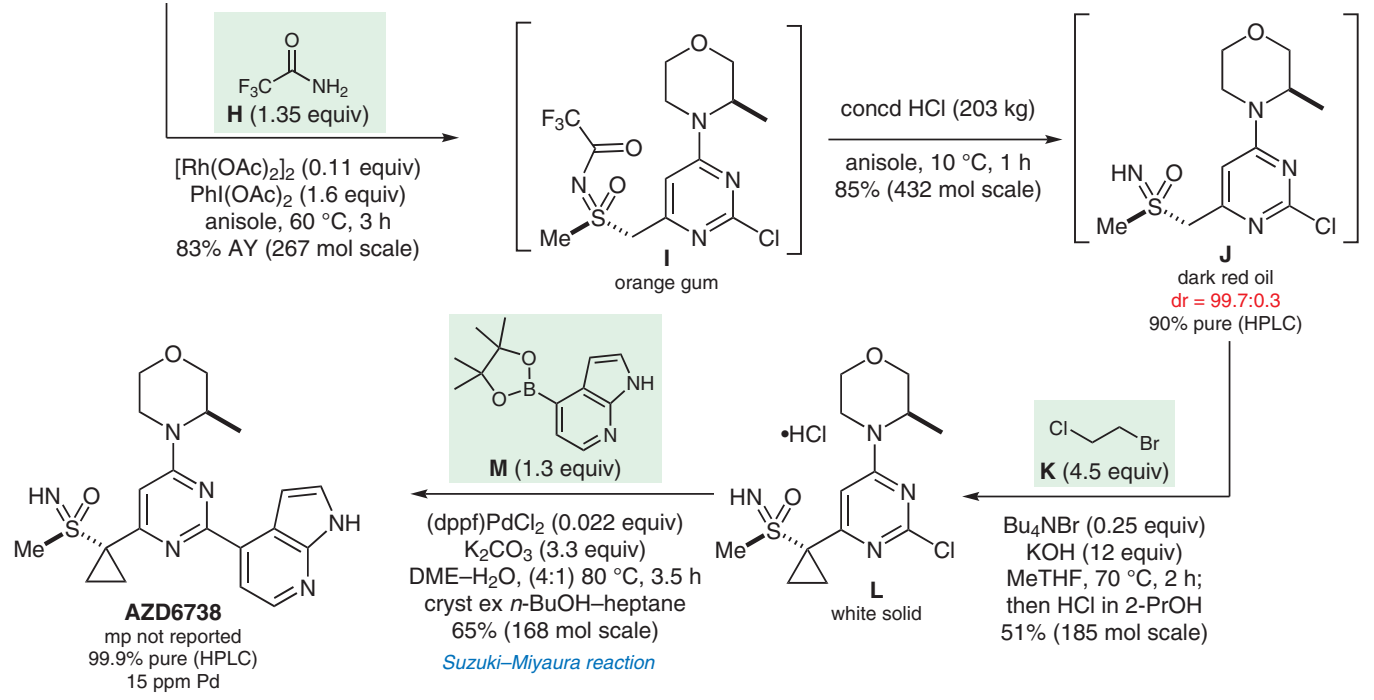

$90 \%$ pure (HPLC)

Key words

AZD6738

asymmetric sulfoxidation

sulfoximines

biocatalysis

rhodium catalysis
Significance: Workers at AstraZeneca recently reported a mol-scale synthesis of ATR inhibitor AZD6738 based on the use of chiral HPLC to access the chiral sulfoxide intermediate $\mathbf{G}$ (J. Med. Chem. $\mathbf{2 0 1 8}, 61,9889)$. A plant scale synthesis of AZD6738 is now reported that features a biocatalytic asymmetric sulfoxidation reaction $(\mathbf{F} \rightarrow \mathbf{G})$ and a cyclopropanation $(\mathbf{J} \rightarrow \mathbf{L})$ in continuous stirred tank reactors.
Comment: The sulfoxidation reaction uses a Baeyer-Villiger monooxygenase in tandem with nicotinamide adenine dinucleotide phosphate (NADPH), which is oxidized to NADP ${ }^{+}$. NADPH is then regenerated through reduction of $\mathrm{NADP}^{+}$by a ketoreductase (KRED) enzyme, which in turn oxidizes the co-solvent isopropanol to acetone. Efficient gas-liquid mass transfer of oxygen is key to obtaining a high yield. 